\title{
Photosynthetic Water Use Efficiency of Heritage and Modern Potatoes under Limited and Unlimited Water Environments
}

\author{
Isaac R. Fandika1,2, Peter D. Kemp¹, James P. Millner¹, Dave Horne ${ }^{1}$ \\ ${ }^{1}$ Institute of Natural Resources, Massey University, Palmerston North, New Zealand \\ ${ }^{2}$ Department of Agricultural Research Services, Kasinthula Agricultural Research Station, \\ Chikwawa, Malawi \\ Email: fandikai@yahoo.co.uk
}

Received 4 November 2014; revised 23 November 2014; accepted 4 December 2014

Copyright @ 2014 by authors and Scientific Research Publishing Inc.

This work is licensed under the Creative Commons Attribution International License (CC BY). http://creativecommons.org/licenses/by/4.0/

(c) (i) Open Access

\begin{abstract}
Photosynthetic capacity for heritage (Taewa) and modern potato cultivars were compared at different water and nitrogenregimes in the glasshouse and field. The glasshouse was $2 * 2 * 4$ factorial design with two irrigation: $100 \% \mathrm{ET}$ and $60 \% \mathrm{ET}$; two applied $\mathrm{N}: 50 \mathrm{~kg} \mathrm{~N} \mathrm{ha}^{-1}$ and $200 \mathrm{~kg} \mathrm{~N} \mathrm{ha}^{-1}$, two Taewa (Moe Moe, Tutaekuri) and two modern potatoes (Moonlight, Agria). The 2009/2010 field experiment was a split-plot, with irrigation and rain-fed regimes as the main treatments: four potatoes above were sub-treatments. The 2010/2011 field experiment was a split-split-plot, with three water regimes as the main treatments: three cultivars (Moe Moe, Tutaekuri, and Agria) were subplots; two $\mathrm{N}$ rates were sub-sub-treatments. Gaseous exchange was measured by CIRAS-2 at different days from emergence. Leaf water potential was measured using pressure chamber method. Taewa achieved high photosynthetic WUE in glasshouse and $2010 / 2011$ experiment by maintaining high $A_{n}$, low $g_{s}$ and low $C i$ compared to modern cultivars $(p<0.0001)$. The $A_{n}, g_{s}$ and $T$ increased with irrigation and $\mathrm{N}$ increase while decreasing $\mathrm{Ci}(\mathrm{p}<0.01)$. Water stress significantly increased VPD resulting in low $A_{n}$ and photosynthetic WUE in Moonlight in the glasshouse. The leaf water potential for Taewa was very tolerant while modern potatoes were weakened by water stress. The study indicated that Taewa can be scheduled at partial irrigation without more detrimental effects on photosynthetic capacity while modern potatoes need full irrigation to avoid detrimental effects on photosynthetic capacity.
\end{abstract}

\section{Keywords}

Taewa, Photosynthesis, Stomatal Conductance $\left(\mathrm{g}_{\mathrm{s}}\right)$, Transpiration ( $\left.\mathrm{T}\right)$, Irrigation, Internal Carbon concentration (Ci), Vapour Pressure Deficit (VPD), Leaf Water Potential, and Photosynthetic Water Use Efficiency (Photosynthetic WUE), Solanum tuberosum, Solanum andigena 


\section{Introduction}

Modern crop cultivars are products of human modification on wild or early crop cultivars through breeding, in order to meet man's interest [1]. Issues of high yields and quality have been great motivation in substituting old cultivars with modern cultivars in Solanum tuberosum [2], Brassica napus ssp. Napobrassica [3], wheat [4], and soybeans [5]. However, it was argued that crop improvement has failed to increase the basis for assimilation (relative growth rate and relative leaf area) despite increasing harvestable organs [6]. Old wheat and oat cultivars were reported to have higher leaf area and growth rate than their modern cultivars [7]. Consequently, low gaseous exchange is reported in modern cultivars compared to old or wild cultivars for cereal crops [6]. It was not known whether the heritage potatoes collectively known as Taewa in New Zealand outweigh modern potatoes in photosynthetic capacity; unravelling of this controversy under different water and nitrogen situation is vital for Taewa growers to easily manage them in the modern production systems.

Potato gaseous exchange is strongly influenced by water and nitrogen $(\mathrm{N})$ apart from leaf features and other environmental factors [8]. Nitrogen is very much prioritised for leaf development before enhancing photosynthetic capacity in potato [9]. This is why leaf ageing comparably declines assimilation rates [10]. A decrease in conductance and assimilation in potato because of low internal carbon concentration (Ci) and high photosynthesis/ stomatal conductance $\left(\mathrm{A}_{\mathrm{n}} / \mathrm{g}_{\mathrm{s}}\right)$ ratio was also reported under water deficit [11]. This contradicted an argument that an increase in $\mathrm{Ci}$ simulates the stomata aperture to reduce $\mathrm{gs}_{\mathrm{s}}$ [12]. Controversies still remains in gaseous exchange between heritage potatoes of New Zealand and modern potato cultivars at different water and $\mathrm{N}$ levels. Progressions of photosynthetic capacity in modern potatoes from heritage potatoes, Taewa was investigated to enable grower manage inputs such as fertilizer and irrigation for optimum production. The response of Taewa to water and $\mathrm{N}$ is important to bridge the yield gap between Taewa and modern potato [2] through optimisation of the interaction between cultivars and crop management. This study compared photosynthetic capacity and leaf water potential of Taewa and modern potatoes grown at different water and $\mathrm{N}$ regimes under glasshouse and field conditions.

\section{Materials and Methods}

\subsection{Location and Establishment}

Three experiments were carried out as follows: Trial 1: in the glasshouse at the Plant Growth Unit, Massey University, Palmerston North from $23^{\text {rd }}$ June to $11^{\text {th }}$ November 2009; Trial 2: as from $10^{\text {th }}$ November, 2009 to May, 2010; Trial 3: as from $27^{\text {th }}$ October 2010 to April 2011. Seed of Taewa, Moe Moe (Solanum tuberosum L.) and Tutaekuri (Solanum andigena Juz. \& Buk.) and modern cultivars, Moonlight and Agria (S. tuberosum L.) were planted in $15 \mathrm{l}$ plastic planting bags in a glasshouse whilst in the field, seed tubers were planted in furrows at $30 \mathrm{~cm}$ between plants and $75 \mathrm{~cm}$ between rows. Soil type was Manawatu sandy loam, a recent alluvial soil. The soil properties were: pH 5.4, Olsen P 36 mg/l, K 0.22 me/100g, and available nitrogen (N) $106 \mathrm{~kg} \cdot \mathrm{ha}^{-1}$. Bulk density was $1.35 \mathrm{~g} \cdot \mathrm{cm}^{-3}$ and volumetric soil water content at field capacity and wilting point were 0.35 and $0.17 \mathrm{~m}^{3} \cdot \mathrm{m}^{-3}$, respectively.

\subsection{Treatment and Experimental Design}

The glasshouse experiment was laid out as a $2 \times 2 \times 4$ factorial experimental design with four replicates (two water regimes $\times$ two $\mathrm{N}$ fertilizer rates $\times$ four potato cultivars. Irrigation treatments in glasshouse were based on reference crop evapotranspiration (ET) and were implemented by applying 60\% ET and 100\% ET to plants every four days up to day 77 after planting, and subsequently, every two days. Irrigation to replenish the planting bags to field capacity was determined by weighing the $B$. napus reference bag before and after irrigation to obtain the mean reference crop evapotranspiration within the irrigation interval. The two $\mathrm{N}$ application rates were $0.70 \mathrm{~g} \mathrm{~N}$ $\left(50 \mathrm{~kg} \mathrm{~N} \mathrm{ha}^{-1}\right)$ and $2.12 \mathrm{~g} \mathrm{~N}\left(200 \mathrm{~kg} \mathrm{~N} \mathrm{ha}^{-1}\right)$ as urea.

The 2009/2010 field experiment was laid out as a split-plot, with rainfall and irrigation regimes as the main treatments, each being randomised and replicated four times. The potato cultivars were sub-treatments. The potatoes received 12N:5.2P:14K:6S + 2Mg + 5Ca, using $500 \mathrm{~kg}$ Nitrophoska Blue TE at planting and this was followed by $100 \mathrm{~kg} \mathrm{~N} \mathrm{ha}^{-1}$ of urea, as a side dressing, on $15^{\text {th }}$ December 2009. The 2010/2011 field experiment was laid out as a split-split-plot, with rainfall $\left(\mathrm{P}_{\mathrm{e}}\right)$, partial irrigation (PI) and full irrigation regimes (FI) as the main 
treatments, each being randomised and replicated four times. Three potato cultivars were sub-treatments and two Nlevels were sub-sub-treatments. Potato received 12N:5.2P:14K: 6S + 2Mg + 5Ca, using $500 \mathrm{~kg} \cdot \mathrm{ha}^{-1} \mathrm{Nitro-}$ phoska Blue TE at planting. All plots received the same amount of fertiliser at planting and this was followed by 20 and $180 \mathrm{~kg} \mathrm{~N} \mathrm{ha}^{-1}$ of urea (as a side dressing) on $10^{\text {th }}$ December 2010.Irrigation was applied with a Trailco boom traveller irrigator and crop water use for irrigated and rain-fed treatments was determined by the soil water balance approach [13].

\subsection{Photosynthetic Water Use Efficiency and Gaseous Exchange Measurements}

Photosynthetic water use efficiency (photosynthetic WUE, $\mu \mathrm{mol} \mathrm{CO} / 2 \mathrm{~m} \mathrm{~mol}_{2} \mathrm{O}$ ) was determined as the ratio of net photosynthesis to transpiration rate [14] [15]. CIRAS-2: A portable photosynthesis system (V2.01) was used to measure leaf stomata conductance $\left(\mathrm{m} \mathrm{mol} \mathrm{CO}_{2} \mathrm{~m}^{2} \mathrm{~s}^{-1}\right)$, net photosynthesis $\left(\mu \mathrm{mol} \mathrm{CO} \mathrm{CO}_{2} \mathrm{~m}^{2}\right)$, transpiration rate ( $\mathrm{m} \mathrm{mol} \mathrm{H}_{2} \mathrm{O} \mathrm{m}^{2} \mathrm{~s}^{-1}$ ), internal $\mathrm{Co}_{2}$ concentration (ppm), leaf vapour pressure deficit $(\mathrm{mb})$ and leaf temperature $\left({ }^{\circ} \mathrm{C}\right.$ ) between $1000-1200 \mathrm{hr}$, on a new expanded leaves ( $3^{\text {rd }}$ leaf on main axis). Photosynthetic Active Radiation ( $\mu$ mol $\mathrm{m}^{2} \mathrm{~s}^{-1}$ ) and reference $\mathrm{CO}_{2}(\mathrm{ppm})$ were respectively maintained at an average of 1400 and 400 , during all the CIRAS measurements. Gaseous exchange for glasshouse during 2009/2010 trial was measured four times between day 20 and 90 after plant emergence (DAE). In 2010/2011, gaseous exchange was measured only once after 90 DAE. In 2010/2011, gaseous exchange was measured only once after 90 DAE.

\subsection{Leaf Water Potential Measurements}

The status of leaf water potential $\left(\Psi_{\mathrm{w}}\right)$ was measured using pressure chamber method (Soil Moisture Equipment Corp., Santa Barbara, CA, USA) in both irrigated and non-irrigated plants [16]. During the first field experiment in 2009/2010, leaf water potential was measured at 2:00 pm, two days after irrigation application. The measurements for second field experiment in 2010/2011 were done in the morning (6:00 - 8:00 am) at the development crop stage. During the first field experiment in 2009/2010, leaf water potential was measured at 2:00 pm, two days after irrigation application whilst in second field experiment in 2010/2011; measurements were done in the morning $(6: 00-8: 00 \mathrm{am})$ at the development crop stage. A leaf to be measured was being cut out using scalpel, each at a time and partly sealed in the pressure chamber. The chamber was pressurised with compressed gas until the distribution of water by the living cell and the xylem appeared on the open end of the xylem conduits [16]. The readings were measured on how much pressure was used to release those droplets.

\subsection{Statistical Analyses}

The data on leaf water potential, photosynthetic WUE and gaseous exchange characteristics were analysed by the General Linear Model (GLM) procedure of the Statistical Analysis System [17], and differences among treatment means were compared by the Least Significant Difference test (LSD) at 5\% probability [18]. Pearson correlation coefficient was used to determine gaseous exchange relationships with photosynthetic WUE.

\section{Results}

\subsection{Photosynthetic Water Use Efficiency $\left(\mu \mathrm{mol} \mathrm{CO} / 2 / \mathrm{m} \mathrm{mol} \mathrm{H}_{2} \mathrm{O}\right)$}

Photosynthetic WUE for the glasshouse was significantly influenced by potato cultivar ( $\mathrm{p}<0.0001$ ) and DAE (p $<0.01$, Table 1). Irrigation and $\mathrm{N}$ affected photosynthetic WUE, on days 50 to 85 only $(\mathrm{p}<0.0001)$, but there was no interaction (Figure 1(a)). On average, Moe Moe and Tutaekuri had the highest photosynthetic WUE. Mean photosynthetic WUE was lowest on day 50 and highest on day 85, although there was no difference between days 20, 65 and 85 (Table 1, Figure 1(a)).

In 2009/2010, photosynthetic WUE significantly varied between water regimes $(\mathrm{p}<0.0001)$ and cultivars (p $<0.001)$ and between measured days ( $<0.0001$, Table 2). On average, Agria had the highest photosynthetic WUE, similar to Moe Moe. Photosynthetic WUE was significantly high under irrigation. It was lowest at Day 21 and it then increased to Day 48, followed by a decrease $(\mathrm{p}<0.0001)$. Moe Moe had the highest photosynthetic WUE under rain-fed, at Day 48 (Figure 1(b)). In 2010/2011, photosynthetic WUE significantly differed between potato cultivars with highest observed Moe Moe as also observed in the glasshouse ( $<<0.01)$. Water and $\mathrm{N}$ regimes did not influence photosynthetic WUE in 2010/2011 ( $>>0.05$, Table 3, Figure 1). 
Table 1. Photosynthetic WUE and gaseous exchange in four potato cultivars under different irrigation and nitrogen regimes in the glasshouse during Year 2009.

\begin{tabular}{|c|c|c|c|c|c|c|}
\hline Water Regime & $\begin{array}{l}\text { Photosynthetic } \\
\text { WUE } \\
(\mu \mathrm{mol} / \mathrm{m} \mathrm{mol})\end{array}$ & 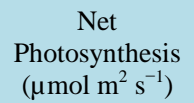 & $\begin{array}{c}\text { Stomatal } \\
\text { Conductance } \\
\left(\mathrm{mmol} \mathrm{m}^{2} \mathrm{~s}^{-1}\right)\end{array}$ & $\begin{array}{l}\text { Transpiration } \\
\left(\mathrm{mmol} \mathrm{m}^{2} \mathrm{~s}^{-1}\right)\end{array}$ & $\begin{array}{c}\text { Internal } \\
\text { Carbon (ppm) }\end{array}$ & $\begin{array}{c}\text { Vapour } \\
\text { Pressure } \\
\text { Deficit (bars) }\end{array}$ \\
\hline \multicolumn{7}{|c|}{ Cultivars $(n=16)$} \\
\hline Moonlight & $6.7^{\mathrm{b}}$ & $10.8^{\mathrm{b}}$ & $116.3^{\mathrm{b}}$ & $1.61^{\mathrm{b}}$ & $223.2^{\mathrm{a}}$ & 16.1 \\
\hline Agria & $6.9^{\mathrm{b}}$ & $12.4^{\mathrm{b}}$ & $142.9^{\mathrm{a}}$ & $1.81^{\mathrm{a}}$ & $206.7^{\mathrm{a}}$ & 14.1 \\
\hline Moe Moe & $8.6^{\mathrm{a}}$ & $14.4^{\mathrm{a}}$ & $122.9^{\mathrm{b}}$ & $1.67^{\mathrm{b}}$ & $160.4^{\mathrm{b}}$ & 15.8 \\
\hline Tutaekuri & $9.4^{\mathrm{a}}$ & $14.2^{\mathrm{a}}$ & $115.6^{\mathrm{b}}$ & $1.51^{\mathrm{b}}$ & $188.6^{\mathrm{b}}$ & 17.5 \\
\hline Significant & $\mathrm{p}<0.001$ & $\mathrm{p}<0.0001$ & $\mathrm{p}<0.05$ & $\mathrm{p}<0.05$ & $\mathrm{p}<0.01$ & Ns \\
\hline \multicolumn{7}{|c|}{ Irrigation $(\mathrm{n}=32)$} \\
\hline $60 \% \mathrm{ET}$ & 8.5 & $10.8^{\mathrm{b}}$ & 123.2 & 1.52 & 170.4 & $17.1^{\mathrm{a}}$ \\
\hline $100 \% \mathrm{ET}$ & 9.2 & $12.6^{\mathrm{a}}$ & 134.1 & 1.61 & 153.1 & $14.8^{\mathrm{b}}$ \\
\hline Significant & Ns & $\mathrm{p}<0.0001$ & Ns & Ns & Ns & $\mathrm{p}<0.05$ \\
\hline \multicolumn{7}{|c|}{ Nitrogen (32) } \\
\hline $50 \mathrm{~kg} \mathrm{~N} \mathrm{ha}^{-1}$ & 9.2 & 10.9 & $118.4^{\mathrm{b}}$ & 1.50 & 153.0 & 15.1 \\
\hline $200 \mathrm{~kg} \mathrm{~N} \mathrm{ha}^{-1}$ & 8.5 & 12.4 & $138.9^{\mathrm{a}}$ & 1.63 & 170.5 & 16.7 \\
\hline Significant & Ns & $\mathrm{p}<0.0001$ & $\mathrm{p}<0.01$ & Ns & Ns & Ns \\
\hline \multicolumn{7}{|c|}{ Days after emergence $(n=64)$} \\
\hline 20 & $9.6^{\mathrm{a}}$ & $17.7^{\mathrm{a}}$ & $130.1^{\mathrm{a}}$ & $1.84^{\mathrm{b}}$ & - & 15.3 \\
\hline 50 & $6.9^{\mathrm{b}}$ & $12.8^{\mathrm{a}}$ & $144.0^{\mathrm{a}}$ & $2.08^{\mathrm{a}}$ & - & 18.1 \\
\hline 65 & $9.3^{\mathrm{a}}$ & $12.3^{\mathrm{a}}$ & $145.1^{\mathrm{a}}$ & $1.52^{\mathrm{b}}$ & 168.8 & 15.1 \\
\hline 85 & $9.8^{\mathrm{a}}$ & $9.1^{\mathrm{b}}$ & $78.8^{\mathrm{b}}$ & $1.15^{\mathrm{c}}$ & 140.6 & 15.1 \\
\hline Significant & $\mathrm{p}<0.01$ & $\mathrm{p}<0.0001$ & $\mathrm{p}<0.0001$ & $\mathrm{p}<0.0001$ & NS & Ns \\
\hline \multicolumn{7}{|l|}{ Interaction } \\
\hline Var."DAE & Ns & $\mathrm{p}<0.0001$ & Ns & Ns & Ns & Ns \\
\hline Var. ${ }^{*} N^{*} I R R$ & Ns & $\mathrm{p}<0.05$ & Ns & Ns & NS & Ns \\
\hline
\end{tabular}
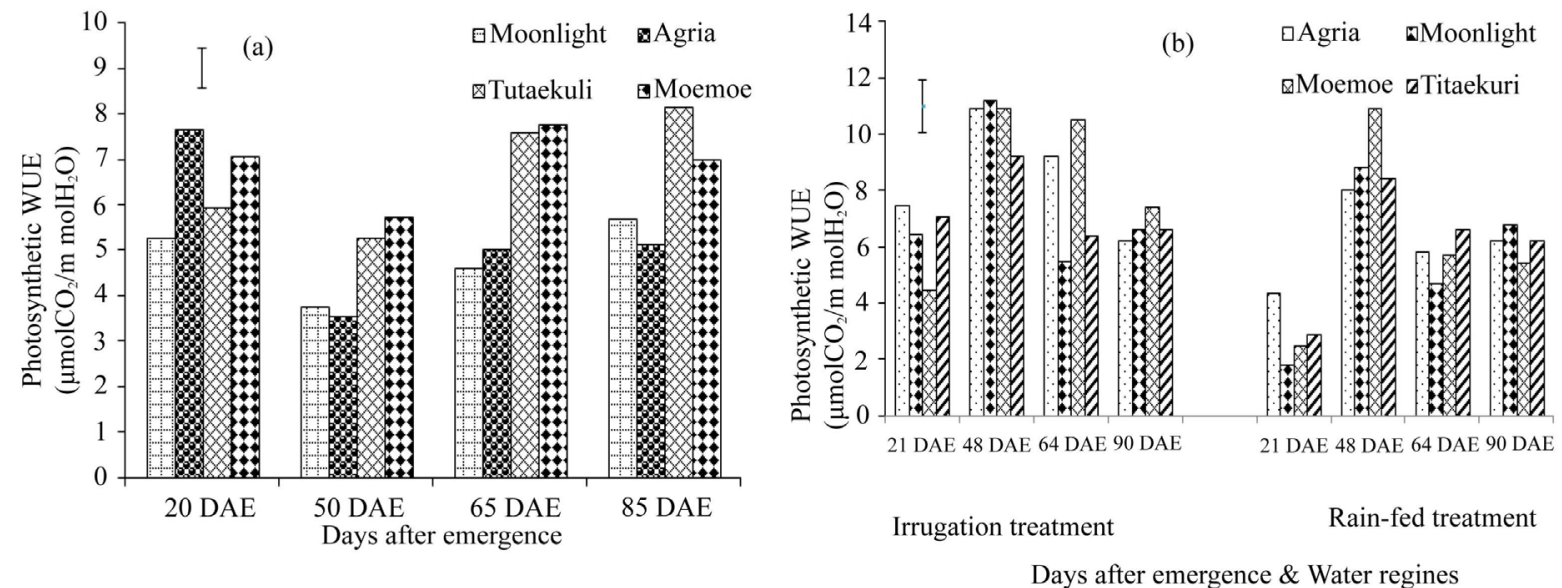

Figure 1. Effect of irrigation on PWUE ( $\mathrm{m} \mathrm{mol} \mathrm{m}^{2} \mathrm{~s}^{-1}$ ) of four potato cultivars in the glasshouse (a) and in the field during year 2009/2010 (b). Error bar represents LSD at 5\%.

\subsection{Net Photosynthesis ( $\mu \mathrm{mol} \mathrm{CO} \mathrm{Cm}^{2} \mathrm{~s}^{-1}$ )}

Net photosynthesis $\left(A_{n}\right)$ significantly differed between cultivars $(p<0.0001)$, irrigation $(p<0.0001)$, $N$ regimes $(\mathrm{p}<0.0001)$ and DAE in the glasshouse, $(\mathrm{p}<0.0001$, Table 1$)$. Taewa (particularly Moe Moe) had the highest average $A_{n}$ rate throughout the growing period, except for Day 20, when Agria had the highest average $A_{n}$. Net 
Table 2. Photosynthetic WUE and gaseous exchange in Taewaand modern potato cultivars under irrigation and rain fed regimes in the field during Year 2010.

\begin{tabular}{|c|c|c|c|c|c|c|}
\hline Water Regime & $\begin{array}{l}\text { Photosynthetic } \\
\text { WUE } \\
\text { ( } \mu \mathrm{mol} / \mathrm{m} \mathrm{mol} \text { ) }\end{array}$ & 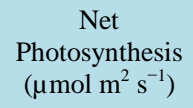 & $\begin{array}{c}\text { Stomatal } \\
\text { Conductance } \\
\left(\mathrm{mmol} \mathrm{m}^{2} \mathrm{~s}^{-1}\right)\end{array}$ & $\begin{array}{l}\text { Transpiration } \\
\left(\mathrm{mmol} \mathrm{m}^{2} \mathrm{~s}^{-1}\right)\end{array}$ & $\begin{array}{c}\text { Internal } \\
\text { Carbon (ppm) }\end{array}$ & $\begin{array}{c}\text { Vapour } \\
\text { Pressure } \\
\text { Deficit (bars) }\end{array}$ \\
\hline \multicolumn{7}{|c|}{ Cultivars $(\mathrm{n}=8)$} \\
\hline Agria & $7.3^{\mathrm{a}}$ & 21.8 & 620.9 & 3.2 & 307.0 & 7.5 \\
\hline Moonlight & $6.5^{c}$ & 19.1 & 663.8 & 3.2 & 307.8 & 6.8 \\
\hline Moe Moe & $7.2^{\mathrm{a}}$ & 21.6 & 660.5 & 3.3 & 317.7 & 6.2 \\
\hline Tutaekuri & $6.8^{\mathrm{b}}$ & 19.4 & 658.3 & 3.1 & 299.7 & 6.2 \\
\hline Significant & $\mathrm{p}<0.001$ & $\mathrm{p}<0.0001$ & Ns & Ns & Ns & Ns \\
\hline \multicolumn{7}{|c|}{ Water regime $(\mathrm{n}=16)$} \\
\hline Irrigation & $7.9^{\mathrm{a}}$ & $20.5^{\mathrm{a}}$ & 687.5 & 3.2 & 294.2 & 6.56 \\
\hline Rain-fed & $5.9^{\mathrm{b}}$ & $14.4^{\mathrm{b}}$ & 616.2 & 3.1 & 321.9 & 6.79 \\
\hline Significant & $\mathrm{p}<0.0001$ & $\mathrm{p}<0.0001$ & Ns & Ns & 0.0001 & Ns \\
\hline \multicolumn{7}{|c|}{ Days after emergence $(n=32)$} \\
\hline 21 & $4.6^{\mathrm{c}}$ & $15.2^{\mathrm{c}}$ & $637.4^{\mathrm{b}}$ & $3.5^{\mathrm{a}}$ & $350.2^{\mathrm{a}}$ & $7.4^{\mathrm{ba}}$ \\
\hline 48 & $9.8^{\mathrm{a}}$ & $24.8^{\mathrm{a}}$ & $753.4^{\mathrm{a}}$ & $2.6^{\mathrm{b}}$ & $286.4^{\mathrm{b}}$ & $4.3^{\mathrm{c}}$ \\
\hline 64 & $6.8^{\mathrm{b}}$ & $21.5^{\mathrm{b}}$ & $584.4^{\mathrm{b}}$ & $3.3^{\mathrm{a}}$ & $298.2^{\mathrm{b}}$ & $8.1^{\mathrm{a}}$ \\
\hline 90 & $6.4^{\mathrm{b}}$ & $20.4^{\mathrm{b}}$ & $632.1^{\mathrm{b}}$ & $3.3^{\mathrm{a}}$ & $297.4^{\mathrm{a}}$ & $6.9^{\mathrm{b}}$ \\
\hline Significant & $\mathrm{p}<0.0001$ & $\mathrm{p}<0.001$ & $\mathrm{p}<0.01$ & $\mathrm{p}<0.01$ & $\mathrm{p}<0.05$ & $\mathrm{p}<0.0001$ \\
\hline
\end{tabular}

Table 3. Photosynthetic WUE and gaseous exchange in Taewa and modern potato cultivars under different water and nitrogen regimes in the field during Year 2011.

\begin{tabular}{|c|c|c|c|c|c|c|}
\hline Treatments & $\begin{array}{c}\text { Photosynthetic } \\
\text { WUE } \\
(\mu \mathrm{mol} / \mathrm{m} \mathrm{mol})\end{array}$ & $\begin{array}{c}\text { Net } \\
\text { Photosynthesis } \\
\left(\mu \mathrm{mol} \mathrm{m} \mathrm{m}^{-1}\right)\end{array}$ & $\begin{array}{c}\text { Stomatal } \\
\text { Conductance } \\
\left(\mathrm{m} \mathrm{mol} \mathrm{m}^{2} \mathrm{~s}^{-1}\right)\end{array}$ & 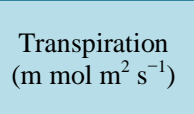 & $\begin{array}{l}\text { Internal } \\
\text { Carbon } \\
\text { (ppm) }\end{array}$ & $\begin{array}{c}\text { Leaf } \\
\text { Temperature } \\
\left({ }^{\circ} \mathrm{C}\right)\end{array}$ \\
\hline \multicolumn{7}{|c|}{ Cultivars $(n=24)$} \\
\hline Agria & $2.8^{\mathrm{b}}$ & $6.8^{\mathrm{b}}$ & $71.0^{\mathrm{bc}}$ & 2.8 & $223.5^{\mathrm{a}}$ & 28.9 \\
\hline Moe Moe & $4.6^{\mathrm{a}}$ & $12.5^{\mathrm{a}}$ & $113.3^{\mathrm{ab}}$ & 2.7 & $158.4^{\mathrm{b}}$ & 29.2 \\
\hline Tutaekuri & $4.3^{\mathrm{a}}$ & $10.8^{\mathrm{a}}$ & $97.8^{\mathrm{b}}$ & 2.6 & $166.6^{\mathrm{b}}$ & 29.2 \\
\hline $\mathrm{LSD}_{0.05}$ & $\mathrm{p}<0.01$ & $\mathrm{p}<0.05$ & $\mathrm{p}<0.05$ & Ns & $\mathrm{p}<0.01$ & Ns \\
\hline \multicolumn{7}{|c|}{ Water regimes $(\mathrm{n}=24)$} \\
\hline FI & 4.3 & $12.6^{\mathrm{a}}$ & $109.3^{\mathrm{a}}$ & $2.9^{\mathrm{ab}}$ & $166.8^{\mathrm{b}}$ & 29.2 \\
\hline PI & 3.1 & $10.9^{\mathrm{a}}$ & $115.4^{\mathrm{a}}$ & $3.5^{\mathrm{a}}$ & $205.5^{\mathrm{a}}$ & 29.2 \\
\hline Rain-Fed & 3.9 & $6.7^{\mathrm{b}}$ & $57.2^{\mathrm{b}}$ & $1.7^{\mathrm{b}}$ & $176.8^{\mathrm{ab}}$ & 28.9 \\
\hline $\mathrm{LSD}_{0.05}$ & Ns & $\mathrm{p}<0.05$ & $\mathrm{p}<0.01$ & $\mathrm{p}<0.05$ & $\mathrm{p}<0.05$ & Ns \\
\hline \multicolumn{7}{|c|}{ Nitrogen $\left(\mathrm{kg} \cdot \mathrm{ha}^{-1}\right)(\mathrm{n}=36)$} \\
\hline 80 & 3.9 & $8.0^{\mathrm{b}}$ & $72.0^{\mathrm{b}}$ & 2.0 & 185.9 & 29.1 \\
\hline 240 & 3.6 & $12.1^{\mathrm{a}}$ & $116.0^{\mathrm{a}}$ & 3.4 & 179.8 & 29.2 \\
\hline $\mathrm{LSD}_{0.05}$ & Ns & $\mathrm{p}<0.05$ & $\mathrm{p}<0.01$ & Ns & Ns & Ns \\
\hline
\end{tabular}

Note: FI and PI refer to full irrigation and partial irrigation respectively.

photosynthesis tended to decrease from Days 20 to 85 ( $p>0.0001$, Figure 2(a)). On average, $A_{n}$ was highest on Day 20, except in Moe Moe, which was highest on both Day 20 and 50 (Figure 2(a)). There was an interaction between DAE*cultivars $(\mathrm{p}<0.001)$ and potato cultivar*irrigation* $\mathrm{N}(\mathrm{p}<0.05)$ for $\mathrm{A}_{\mathrm{n}}$. High irrigation and high $\mathrm{N}$ increased $\mathrm{A}_{\mathrm{n}}$ in modern cultivars, whilst it decreased it in Taewa, with the largest reduction being in Tutaekuri (Figure 2(b)).

In 2009/2010, $A_{n}$ significantly varied between potato cultivars, irrigation and DAE ( $<<0.0001$, Table 2). Agria and Moe Moe had the highest $A_{n}$ under irrigation and rain-fed conditions, respectively. The average seasonal $A_{n}$ for the two cultivars did not vary $(p>0.05)$. There was a consistent pattern of increasing and then de- 


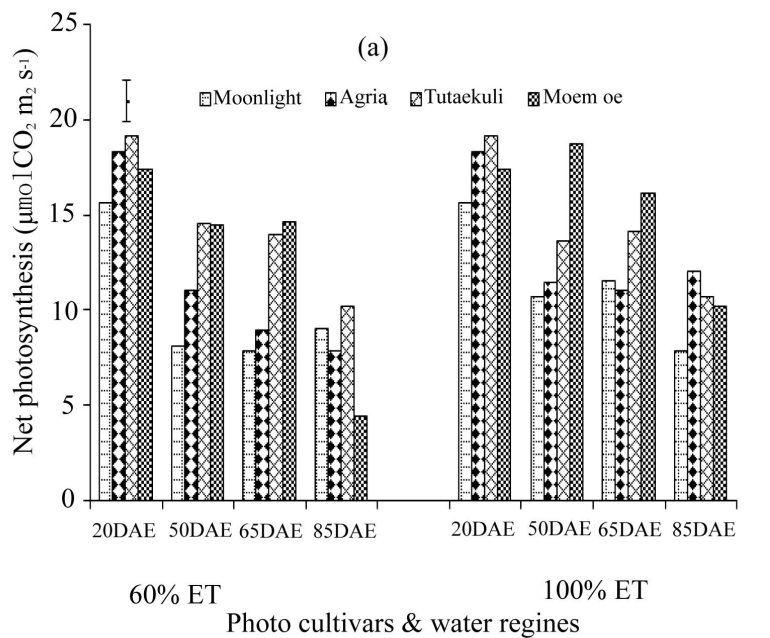

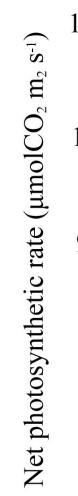

(c)

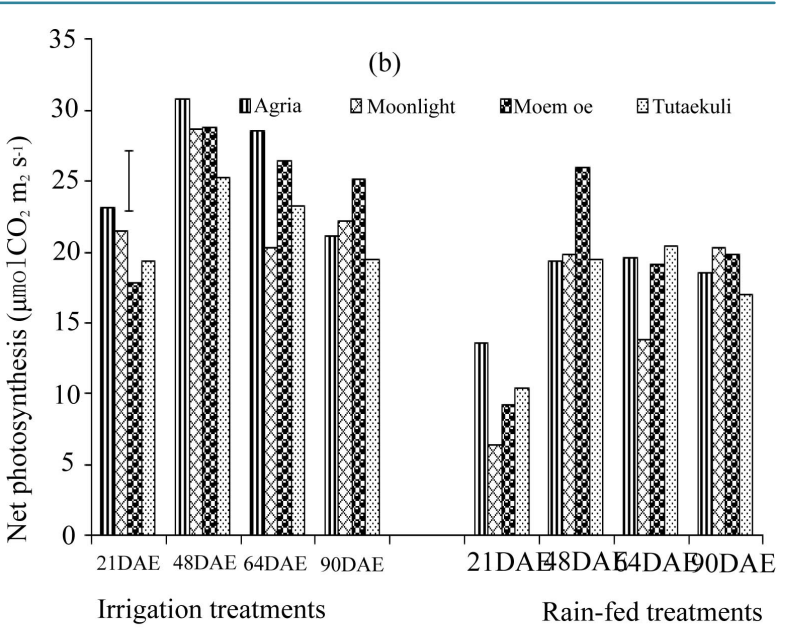

Days after plant emergence

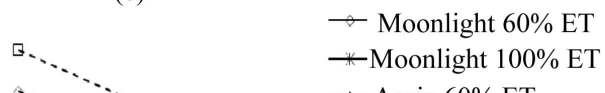

* $\cdots$.

*

(

I $-\cdots$-Tutaekuri $100 \%$ ET
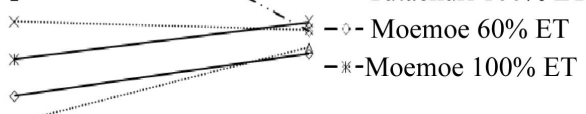

50 Nitrogen $\left(\mathrm{kg} \mathrm{ha}^{-1}\right) \quad 200$

Figure 2. Net photosynthesis ( $\mu \mathrm{mol} \mathrm{CO} \mathrm{CO}_{2} \mathrm{~s}^{-1}$ ) of four potato cultivars in the glasshouse (a); And in the year 2009/2010 field experiment (b); Error bar represents LSD at 5\%; (c) Interaction between irrigation, nitrogen and potato cultivars on $A_{n}$ in the glasshouse during Year 2009. The Y-axis is $\mathrm{A}_{\mathrm{n}}\left(\mu \mathrm{mol} \mathrm{CO} \mathrm{CO}^{2} \mathrm{~s}^{-1}\right)$. Error bar represents $\pm \mathrm{SEM}$.

creasing $A_{n}$ from early measurements to later days ( $\left.p<0.0001\right)$. Netphotosynthesis was greatest on Day 48 in both irrigated and rain-fed potato (Figure 2(b)). In the 2010/2011, $A_{n}$ was significantly influenced by potato cultivars, irrigation and $\mathrm{N}$ regimes $(\mathrm{p}<0.05)$. Increase of irrigation and $\mathrm{N}$, increased photosynthesis, with highest observed in Taewa (especially Moe Moe) and lowest in modern cultivar, Agria (Table 3).

\subsection{Stomatal Conductance ( $\left.\mathrm{m} \mathrm{mol} \mathrm{CO} \mathrm{m}^{2} \mathrm{~s}^{-1}\right)$}

Stomatal conductance $\left(g_{s}\right)$ for glasshouse, significantly differed with cultivars $(p<0.05), N(p<0.01)$ and DAE ( $p<0.0001$, Table 1). The $g_{s}$ significantly increased up to Day 65 under both irrigation and Day 50 under rain-fed, and then decreased (Figure 3). Nitrogen enhanced $g_{s}$ whilst irrigation influence was observed on Day 50 ( $\mathrm{p}<0.05$ ). In most cases, the modern cultivar, Agria, had the highest $\mathrm{g}_{\mathrm{s}}$, whilst the Taewa (particularly Moe Moe), had the lowest $g_{s}$. The $g_{s}$ only differed between measured days in the glasshouse and in the 2009/2010 study with the highest $g_{s}$ on Day 65 and 48 in Moonlight, respectively ( $<<0.01$, Table 2). Cultivars and irrigation had no significant effect on $g_{s}$ in 2009/2010 (p > 0.05). In 2010/2011, $g_{s}$ was influenced by potato cultivars, irrigation and $\mathrm{N}$ regimes $(\mathrm{p}<0.05, \mathrm{p}<0.01)$. Moe Moe had highest $\mathrm{g}_{\mathrm{s}}$. The rain-fed treatment had restricted $\mathrm{g}_{\mathrm{s}}$ resulting in low $A_{n}$. Increase in irrigation and $\mathrm{N}$ level, increased $g_{s}$ and $A_{n}$ (Table 3 ).

\subsection{Transpiration Rate ( $\left.\mathrm{m} \mathrm{mol} \mathrm{H} \mathrm{O} \mathrm{m}^{2} \mathrm{~s}^{-1}\right)$}

Transpiration rates $(\mathrm{T})$ were influenced by cultivar $(\mathrm{p}<0.05)$ and DAE in the glasshouse $(\mathrm{p}<0.0001$, Table 1$)$. Agria had the greatest $\mathrm{T}$, whilst Tutaekuri had the lowest $\mathrm{T}$. The maximum transpiration, for almost all cultivars, was on Day 50, when irrigation had a significant effect on $\mathrm{T}$ and the lowest $\mathrm{T}$ was on Day 85 (p $<0.05$ ). The 


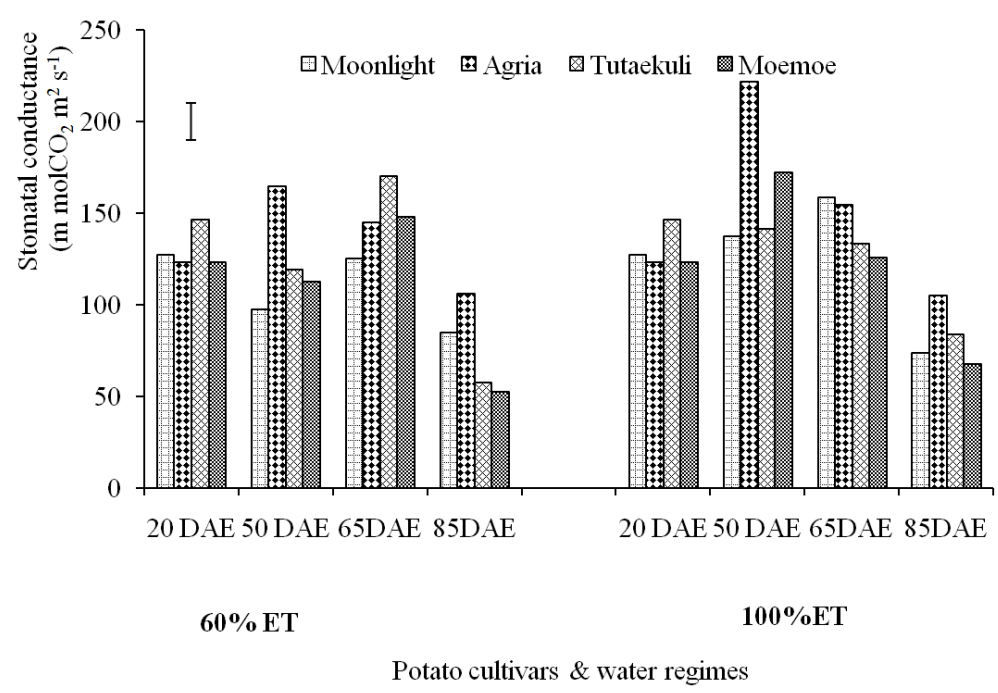

Figure 3. Effect of water regime on stomatal conductance $\left(\mathrm{m} \mathrm{mol} \mathrm{CO} \mathrm{Cm}^{2} \mathrm{~s}^{-1}\right.$ ) of four potato cultivars during the growth period under glasshouse condition during Year 2009. Error bar represents LSD at 5\%.

general trend was that the cultivar with the highest $g_{s}$ also had the highest $T$ and lower $A_{n}$. In 2009/2010, $T$ only differed between measured days, with the highest $g_{s}$ and lowest $T$ on Day 48 in Moonlight $(p<0.01$, Table 2). Potato cultivars and irrigation had no significant effect on $\mathrm{T}(\mathrm{p}>0.05)$. Transpiration was enhanced by irrigation in 2010/2011 ( $<$ 0.05) while water restriction reduced it (Table 3).

\subsection{Internal $\mathrm{CO}_{2}$ Concentration, Leaf Temperature $\left({ }^{\circ} \mathrm{C}\right.$ ) and Vapour Pressure Deficits (mb)}

Moonlight and Agria had the greatest internal carbon concentration (Ci) whilst Taewa had the lowest $\mathrm{Ci}$ in the glasshouse ( $<<0.0001$, Table 1$)$. Vapour pressure deficit (VPD) was not statistically different between cultivars ( $p>0.5$ ), but between water regimes ( $p<0.0001)$. Irrigation significantly reduced leaf VPD and Ci $(\mathrm{p}<0.0001)$, whilst N did not affect both VPD and Ci ( $<<0.0001$, Tables 1-3). In 2009/2010, Ci was highest on Day 21 and lowest at Day $90(\mathrm{p}<0.0001)$ with no statistical differences between irrigation and cultivars $(\mathrm{p}>0.05)$. Irrigation significantly reduced $\mathrm{Ci}$ while VPD differed between DAE but not between cultivars, $\mathrm{N}$ and irrigation ( $\mathrm{p}>$ 0.05). In the 2010/2011 trial $\mathrm{Ci}$ was also found highest in Agria and partially irrigated treatments $(\mathrm{p}<0.01, \mathrm{p}<$ $0.5)$. The $\mathrm{Ci}$ was not statistically different in partially irrigated, rain-fed treatments and between Nitrogen treatments $(p>0.05)$. Leaf temperature was not affected by irrigation, cultivars and $N(p>0.05$, Tables $1-3)$.

\subsection{Photosynthetic WUE and Gaseous Exchange Variables Relationship}

The relationship between photosynthetic WUE and other gaseous exchange variables was explored, by using simple correlation. With all the data combined, there was a correlation between photosynthetic WUE and $\mathrm{T}(\mathrm{r}=$ $0.58, \mathrm{p}<0.0001)$, $\mathrm{g}_{\mathrm{s}}(\mathrm{r}=-0.45, \mathrm{p}<0.0001)$, leaf temperature $(\mathrm{r}=-0.46, \mathrm{p}<0.0001), \mathrm{A}_{\mathrm{n}}(\mathrm{r}=0.35, \mathrm{p}<0.0001)$, Ci $(\mathrm{r}=-0.45, \mathrm{p}<0.0001)$ and VPD $(\mathrm{r}=-0.012, \mathrm{p}>0.05)$. When data were stratified by cultivars, a moderately strong negative $(\mathrm{p}<0.0001)$ correlation was identified with $\mathrm{T}, \mathrm{LT}, \mathrm{g}_{\mathrm{s}}$ and $\mathrm{Ci}$, in all cultivars. The correlation between $\mathrm{Ci}$ and $\mathrm{T}$ was very strong in the modern cultivars, compared to Moe Moe. When stratified by irrigation, photosynthetic WUE strongly correlated $(\mathrm{p}<0.0001)$ to $\mathrm{T}$, $\mathrm{g}_{\mathrm{s}}, \mathrm{LT}, \mathrm{A}_{\mathrm{n}}, \mathrm{Ci}$; $60 \mathrm{ET} \%(\mathrm{r}=-0.52, \mathrm{r}=-0.42, \mathrm{r}=-0.35$, $r=0.31, r=-0.02)$ and $100 \%$ ET $(r=-0.68,-0.58,-0.58,0.039,-0.66)$, respectively. Data stratified by $N$ analysis revealed a correlation between photosynthetic WUE and T, $\mathrm{g}_{\mathrm{s}}$, leaf temperature, $\mathrm{A}_{\mathrm{n}}$, Ci; low N (p< $0.0001)(\mathrm{r}=-0.62,-0.53,-0.48,0.31,-0.28,0.05)$ and high $\mathrm{N}(\mathrm{p}<0.0001),(\mathrm{r}=-0.52,-0.41,-0.41,0.45$, -0.72 ), respectively. There were no correlations between photosynthetic WUE and leaf VPD.

\subsection{Leaf Water Potential $\left(\Psi_{\mathrm{w}}\right)$}

Leaf water potential $\left(\Psi_{\mathrm{w}}\right)$ was significantly influenced by water regime $(\mathrm{p}<0.01)$ and not by cultivars in the 
2009/2010 study ( $p>0.05$, Table 4). The rain-fed plants had highest leaf water potential compared to irrigated plants. The modern potato, Agria, exhibited the greatest leaf water potential among the potato cultivars though not different from each other ( $p>0.05)$. In 2010/2011, leaf water potential $\left(\Psi_{w}\right)$ was significantly influenced by water regime $(p<0.0001)$ and cultivars $(p>0.05)$. The rain-fed plants had highest leaf water potential compared to fully and partially irrigated plants (Table 5). Similarly, Agria had the largest leaf water potential among the three cultivars and it was significantly different from Tutaekuri but not from Moe Moe. Moe Moe and Tutaekuri were not different in leaf water potential $(p>0.05)$. Nitrogen levels did not affect the leaf water potential (p > 0.05, Table 5).

\section{Discussion}

Gaseous exchange is reported to greatly differ with leaf age [10] [19], genotypes [20], atmospheric water demand or irrigation [21] [22], nitrogen [10] [23] and climatic factors in potatoes [24]. Severe water stress is said to accelerate leaf VPD in plants [25] [26]. The implication of a high VPD gradient results in leaf water deficits declining $A_{n}$ and $T$ rate [25]. However, the extent of these environmental factors effects on gaseous exchange [24], depends on genotypes and leaf age.

Photosynthetic WUE and $A_{n}$ initially increased before declining with time and crop age, in all cultivars, regardless of irrigation and $\mathrm{N}$ treatment. This result has also been reported by [10]. Figures for photosynthetic WUE and $A_{n}$ were remarkably high, from 20 to 50 DAE. Generally, modern potatoes had high $A_{n}$ within the first three weeks from emergence, but Taewa had extended high $A_{n}$ up to 65DAE. The tendency for photosynthetic WUE and $A_{n}$ decrease was greatest in the modern potatoes (Agria and Moonlight), possibly due to early maturity, compared to Taewa. A high $A_{n}$ within 20 DAE as observed in the glasshouse was once reported [10]. It was then concluded that this period had raised $A_{n}$ due to tuberisation. A rise in $A_{n}$ with tuberisation in potato has also been reported [27]. In these studies, heritage potatoes, Taewa delayed tuberisation, hence their extended high gaseous exchange.

The highest photosynthetic WUE and $A_{n}$ in the field study was on 48DAE, in both Taewa and modern potatoes. Contrary to the findings on glasshouse by Ghosh [10]. The photosynthetic capacity trend in both glasshouse and field experiment still reflected tuberisation and it declined with age [10] [22]. This suggests that the period of tuberisation, the likely cause of high $A_{n}$ [27], is not static at 21 DAE, as observed in the glasshouse, but it ranges from three weeks to seven weeks from plant emergence and is longer in unimproved cultivars. The extension of high gaseous exchange in Taewa proves that growth stages and maturity period for Taewa are different and longer compared to modern potato cultivars.

Taewa, achieved high photosynthetic WUE in the glasshouse and in 2010/2011 by maintaining high $A_{n}$ at low $\mathrm{Ci}$, compared to Agria and Moonlight. Taewa and Moonlight had comparable $\mathrm{g}_{\mathrm{s}}$ and $\mathrm{T}$ in the glasshouse. In 2009/2010, Moe Moe and Agria had comparable photosynthetic WUE, $A_{n}$ and insignificant $g_{s}, T, C i$ and VPD. However, emphasis on glasshouse and the 2009/2010 field study results found that $A_{n}$ and photosynthetic WUE in Agria, steadily reduced when both $g_{s}$ and $T$ are very high while the 2010/2011 results suggest that Agria does not steadily increase $A_{n}$ even if $g_{s}$ and $T$ are low or comparable to Taewa cultivars, Moe Moe. The main driver of these differences was $\mathrm{Ci}$, which was high in the modern potatoes and low in Taewa.

Photosynthetic WUE is negatively correlated with $\mathrm{Ci}$, particularly in modern cultivars whilst $A_{n}$ and $g_{s}$ relationship is curvilinear (Figure 4). Consequently, $\mathrm{Ci}$ increase and too high $\mathrm{g}_{s}$ in modern potatoes reduced $\mathrm{A}_{n}$ and photosynthetic WUE. This finding agrees with other studies, which have indicated that increased Ci reduces $A_{n}$ [12] and $A_{n}$ and $g_{s}$ relationship is curvilinear [28]. For this reason, Taewa differs from modern potatoes in photosynthetic WUE, in the way Ci manipulates stomata apertures. It is very possible that modern potatoes have changed gaseous exchange behaviour through breeding [12], thereby resulting in disparity in photosynthetic WUE with heritage cultivars, Taewa. The heritage cultivars have not undergone several breeding processes to change its gaseous exchange like modern potatoes [11]. This state may assist Taewa to endure water stress.

Water deficit increases leaf VPD in potato [25], which consequently reduces $g_{s}$ and photosynthetic capacity [23] [29] [22]. In our studies, the $A_{n}$, $g_{s}$ and $T$ increased with irrigation and $N$, whereas leaf VPD and Ci declined with irrigation and $\mathrm{N}$ : Although $\mathrm{N}$ had no much significant influence as irrigation. It was also observed that VPD was significantly influenced by water deficit, thus resulting in low $A_{n}$ and photosynthetic WUE. This shows that a reduction of irrigation, below optimal levels, affects gaseous exchange in both Taewa and modern potatoes: Although this differs. Nevertheless, Taewa exhibited exceptionally high photosynthetic WUE characteristics under 
Table 4. Effect of water regimes on leaf water potential (bars) in heritage and modern potato cultivars during Year 2010.

\begin{tabular}{ccccccc}
\hline Water regime & \multicolumn{2}{c}{ Potato cultivars } & \multirow{2}{*}{ Mean $(\mathrm{n}=16)$} \\
\hline Irrigation & Moonlight & Agria & Tutaekuri & Moemoe & $6.8^{\mathrm{b}}$ \\
Rain-fed & 6.2 & 7.3 & 6.0 & 7.5 & 8.1 & $8.3^{\mathrm{a}}$ \\
Mean (n=8) & 7.3 & 9.0 & 8.7 & 7.8 & Ns \\
Significance & 6.8 & 8.1 & 7.4 & & $<0.01$ \\
& Cultivars & & & & 1.114 \\
\hline LSD $_{0.05}$ & Water regime & & & & & \\
\hline
\end{tabular}

Note: Insignificance is shown by same letters in columns or rows $(\mathrm{p}>0.05)$.

Table 5. Effect of water and nitrogen regimes on leaf water potential (bars) in heritage and modern potato cultivars during Year 2011.

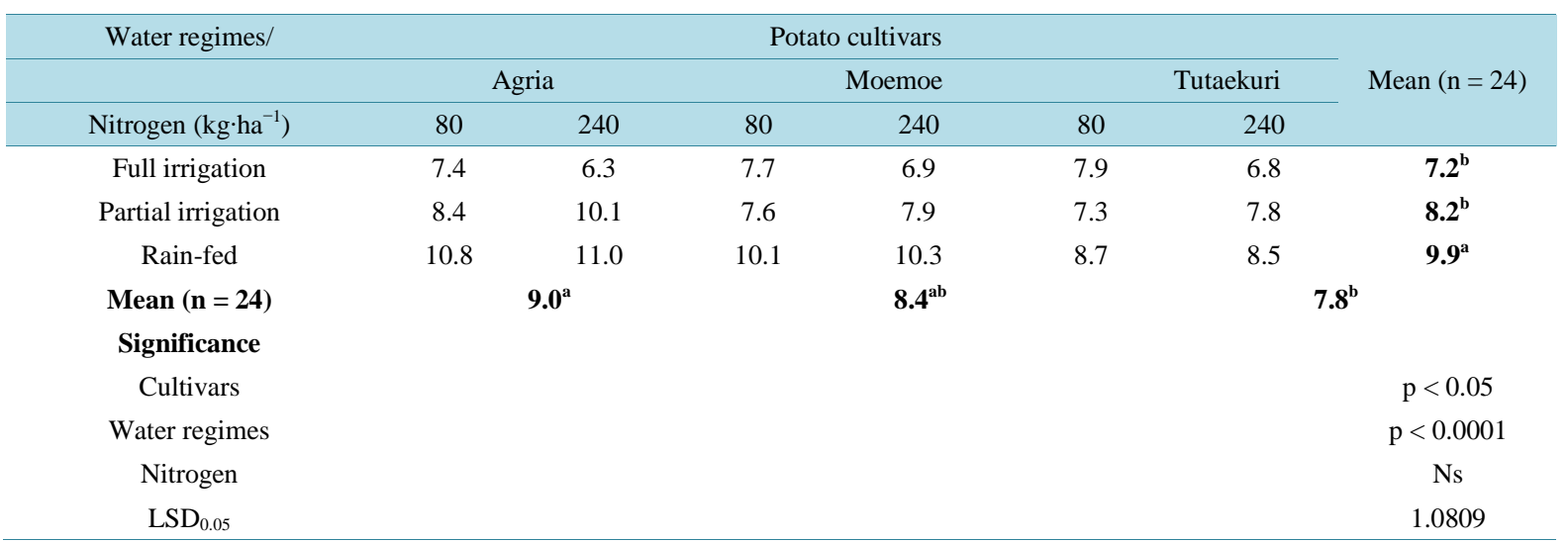

Note: Insignificance is shown by same letters in columns or rows ( $p>0.05)$.

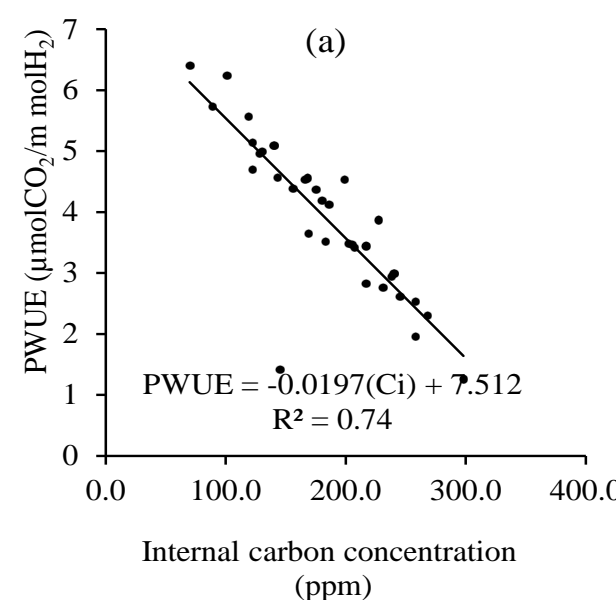

(ppm)

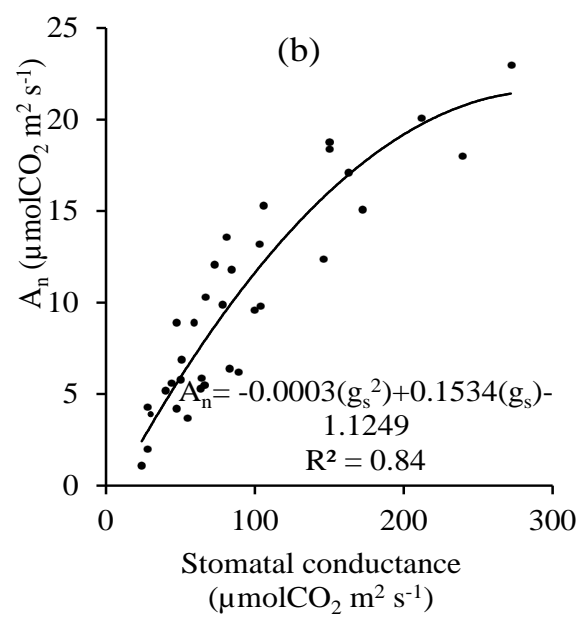

(a) and between net Figure 4. Relationship between photosynthetic WUE (PWUE) and Ci
photosynthesis $\left(A_{n}\right)$ and $g_{s}$; (b) in potato cultivarsduring Year 2010/2011.

water stress. This ability suggests they are well adapted to low water supply as once reported in old wheat compared to their modern wheat [30] and among potato genotypes [31].

There are potato genotypic variation in $A_{n}$ under well watered and limited water [31]. However, the response to water deficit was primary regulated by stomatal closure followed by mesophyllic activity when water stress was severe, as also observed in this study and in most $C_{3}$ plants [32]. The Ci for rain-fed treatment in the 2009/2010 field study increased, thus signifying severe water stress to have fully induced $A_{n}$ and photosynthetic 
WUE reduction in modern potatoes. This is factual, because Ci is greatly affected by mesophyllic activity [31] and it is inversely related to $A_{n}$ [12]. However, this study results differ from Olensinski study [23], who found that $\mathrm{Ci}$ was not affected by water deficit and it also opposes Liu's findings [15] that photosynthetic WUE was higher under deficit irrigation than full irrigation.

Photosynthetic WUE for rain-fed was lower than irrigated crops, possibly because $A_{n}$ for rain-fed decreased, while $g_{s}$ and $T$ remained in the same range with the irrigated potato in the glasshouse and in the 2009/2010 field experiment, which is contrary to other studies [22] and [15]. In 2010/2011, both water and N deficits steadily decreased $\mathrm{g}_{\mathrm{s}}$ as once reported by Schapendonk [31]. Consequently, $\mathrm{T}$ and $\mathrm{A}_{\mathrm{n}}$ reduced under rain-fed and low $\mathrm{N}$, as reported by Olesinski [23]. In contrast to rain-fed, partially irrigated potato achieved the highest Ci, $\mathrm{g}_{\mathrm{s}}$ and T, which consequently increased photosynthetic capacity, whilst reducing photosynthetic WUE due to high T. On the other hand, full irrigation moderately increased $\mathrm{T}$ and $\mathrm{g}_{\mathrm{s}}$ with reduced $\mathrm{Ci}$, hence the high photosynthetic WUE and $A_{n}$. This result suggests that high water stress decreased $g_{s}$ whilst partial water stress reduced the resistance with great $\mathrm{T}$ and $\mathrm{Ci}$ fluxes. Full irrigation stabilised $\mathrm{g}_{s}, \mathrm{Ci}$ and $\mathrm{T}$, resulting in high $\mathrm{A}_{\mathrm{n}}$ and photosynthetic WUE. Consequently, photosynthetic WUE was highest with FI and lowest with PI, despite its high $A_{n}$. The high fluxes in $\mathrm{Ci}$ and $\mathrm{T}$ under PI reduced its photosynthetic WUE. This finding confirms that water and $\mathrm{N}$ deficiencies limit photosynthetic capacity [23] [32], whereas FI and PI improve photosynthetic capacity [22]. However, PI failed to use water sparingly on a canopy basis, as reported under a partial root zone drying irrigation strategy [22], because of very high T soon after irrigation.

Water stress increased leaf water potential in both 2009/2010 and 2010/2011 experiments. However, the leaf water potential results for the 2009/2010 study did not demonstrate genotypic variability on leaf water potential possibly due to low drought intensity compared to 2010/2011, when they differed in leaf water potential, as once reported in the Andean region between water regimes [33]. The 2009/2010 study finding illustrated that potato leaf water potential is not as sensitive as gaseous exchange to water stress and hence it was not a very reliable indicator for cultivar tolerance to water stress, as formerly observed [23]. Regardless to Olesinskiobersation and 2009/2010 study findings, the 2010/2011 experiment showed that leaf water potential can also be used as an indicator for water stress among potato cultivars and for irrigation guidance. Leaf water potential possibly provided good comparison between Taewa and modern potato cultivars when drought intensity was high in 2010/ 2011 compared to the 2009/2010 growing season. The reason is that a high water vapour gradient results in leaf water deficits declining $A_{n}$ and $T$ rate [25] because of stomatal closure induced by high leaf water potential approached after maximum leaf transpiration and water deficits [19].

Taewa demonstrates high tolerance to drought and low $\mathrm{N}$ compared to modern potatoes. An examination of the gaseous exchange behaviour in Taewa, compared to Agria (as presented above) coupled with the leaf water potential results, supports Taewa's superior photosynthetic capacity under water stress. Furthermore, the leaf water potential for FI and PI is not statistically different in Taewa while different in modern potato, Agria. This indicate that Taewa (specifically Tutaekuri), can be scheduled at PI without more water stress while modern potato, Agria, need FI for same leaf water potential with Taewa at PI. Taewa does not require a high amount of $\mathrm{N}$ and water for $A_{n}$ maintenance because is not bred for high water and $\mathrm{N}$ use efficiency as once reported between wild and modern potatoes [34] [35]. Nevertheless, optimal water is a requirement in Moe Moe and the modern potatoes for maximum gas exchange during the growing season.

\section{Conclusion}

There were significant variations on gaseous exchange and leaf water potential between heritage and modern potatoes under different water and $\mathrm{N}$ regimes. It has been proven that photosynthetic WUE and $\mathrm{A}_{\mathrm{n}}$ increased by irrigation and $\mathrm{N}$ in all cultivars. Taewa outweighed modern potatoes on photosynthetic capacity and leaf water potential resilience to water stress in glasshouse and during 2010/2011 experiment. The usual drift of seasonal photosynthetic capacity increasing with tuberisation before declining with time was also observed, except that the decline was high in modern potatoes. The fact was that modern potatoes were more controlled by high Ci compared to Taewa under water stress. That resulted on the build-up propositions of great disparity in photosynthetic capacity among these potato cultivars. Nevertheless, Taewa cultivars are exceptionally able to adapt to low water and $\mathrm{N}$ supply. An examination of the $\mathrm{g}_{\mathrm{s}}$ and leaf water potential behaviour of Taewa at different soil moisture and $\mathrm{N}$ compared to Agria, indicates their competency to decrease $\mathrm{T}$ and maintain high photosynthetic capacity under water and $\mathrm{N}$ deficit environments. This study indicates that Taewa can be scheduled at PI and $\mathrm{N}$ without more water and $\mathrm{N}$ stress while modern potatoes need FI and $\mathrm{N}$. 


\section{References}

[1] Evans, L.T., Ed. (1993) Crop Evolution, Adaptation and Yield. Cambridge University Press, Cambridge.

[2] Harris, G. and Niha, P.P. (1999) Maori Potato. Working Paper. The Open Polytechnic of New Zealand.

[3] Gowers, S., Butler, R.C. and Armstrong, S.D. (2006) Yield Comparison of Old and New Cultivars of Swedes (Brassica napus ssp. Napobrassica) in Southland, New Zealand. New Zealand Journal of Crop and Horticulture, 34, 109114. http://dx.doi.org/10.1080/01140671.2006.9514394

[4] Siddique, K., Tennant, D., Perry, M. and Belford, R. (1990) Water Use and Water Use Efficiency of Old and Modern Wheat Cultivars in a Mediterranean-Type Environment. Australian Journal of Agricultural Research, 41, 431-447. http://dx.doi.org/10.1071/AR9900431

[5] Frederick, J.R., Woolley, J.T., Hesketh, J.D. and Peters, D.B. (1991) Seed Yield and Agronomic Traits of Old and Modern Soybean Cultivars under Irrigation and Soil Water-Deficit. Field Crops Research, 27, 71-82. http://dx.doi.org/10.1016/0378-4290(91)90023-O

[6] Gifford, R.G. and Evans, L.T. (1981) Photosyntheis, Carbon Partitioning and Yield. Annual Review of Plant Physiology, 32, 485-509. http://dx.doi.org/10.1146/annurev.pp.32.060181.002413

[7] Siddique, K., Tennant, D., Perry, M. and Belford, R. (1990) Water Use and Water Use Efficiency of Old and Modern Wheat Cultivars in a Mediterranean-Type Environment. Australian Journal of Agricultural Research, 41, 431-447. http://dx.doi.org/10.1071/AR9900431

[8] Chapman, H.W. and Loomis, W.E. (1953) Photosynthesis in the Potato under Field Conditions. Plant Physiology, 28, 703-716. http://dx.doi.org/10.1104/pp.28.4.703

[9] Vos, J. (1997) The Nitrogen Response of Potato (Solanum tuberosum L.) in the Field: Nitrogen Uptake and Yield, Harvest Index and Nitrogen Concentration. Potato Research, 40, 237-248. http://dx.doi.org/10.1007/BF02358249

[10] Ghosh, S.C., Asanuma, K., Kusutani, A. and Toyota, M. (2000) Gas Exchange Properties of Potato Plants under Different Nitrogen Regimes. Pakistan Journal of Biological Science, 3, 1664-1667.

[11] Vos, J. and Groenwold, J. (1989) Characteristics of Photosynthesis and Conductance of Potato Canopies and the Effects of Cultivars and Transient Drought. Field Crops Research, 20, 237-250. http://dx.doi.org/10.1016/0378-4290(89)90068-3

[12] Morison, J.I.L. (1987) Intercellular $\mathrm{CO}_{2}$ Concentration and Stomatal Response to $\mathrm{CO}_{2}$. In: Zeiger, E., Farquhar, G.D. and Cowan, I.R., Eds., Stomatal Function, Stafford University Press, Stafford, 229-251.

[13] Allen, R.G., Pereira, L.S., Raes, D. and Smith, M. (1998) Crop Evapotranspiration-Guidelines for Computing Crop Water Requirements-FAO Irrigation and Drainage Paper 56. FAO-Food and Agriculture Organization of the United Nations, Rome.

[14] Tanner, C.B. (1981) Transpiration Efficiency of Potato. Agronomy Journal, 73, 59-64. http://dx.doi.org/10.2134/agronj1981.00021962007300010014x

[15] Liu, F., Shahnazari, A., Andersen, M.N., Jacobsen, S.E. and Jensen, C.R. (2006) Effects of Deficit Irrigation (DI) and Partial Root Drying (PRD) on Gas Exchange, Biomass Partitioning, and Water Use Efficiency in Potato. Scientia Horticulturae, 109, 113-117. http://dx.doi.org/10.1016/j.scienta.2006.04.004

[16] Boyer, J.S. (1995) Measuring the Water Status of Plants and Soils. Academic Press, New York.

[17] SAS (2008) SAS Procedures Guide-Version 9.2 Edition.

[18] Meier, U. (2006) A Note on the Power of Fisher's Least Significant Difference Procedure. Pharmaceutical Statistics, 5, 253-263. http://dx.doi.org/10.1002/pst.210

[19] Vos, J. and Oyarzún, P.J. (1987) Photosynthesis and Stomatal Conductance of Potato Leaves—Effects of Leaf Age, Irradiance, and Leaf Water Potential. Photosynthesis Research, 11, 253-264. http://dx.doi.org/10.1007/BF00055065

[20] Tekalign, T. and Hammes, P.S. (2005) Growth and Productivity of Potato as Influenced by Cultivar and Reproductive Growth: II. Growth Analysis, Tuber Yield and Quality. Scientia Horticulturae, 105, 29-44. http://dx.doi.org/10.1016/j.scienta.2005.01.021

[21] Jefferies, R.A. and Mackerron, D.K.L. (1993) Responses of Potato Genotypes to Drought. II. Leaf Area Index, Growth and Yield. Annals of Applied Biology, 122, 105-112. http://dx.doi.org/10.1111/j.1744-7348.1993.tb04018.x

[22] Ahmadi, S.H., Andersen, M.N., Plauborg, F., Poulsen, R.T., Jensen, C.R., Sepaskhah, A.R. and Hansen, S. (2010) Effects of Irrigation Strategies and Soils on Field-Grown Potatoes: Gas Exchange and Xylem [ABA]. Agricultural Water Management, 97, 1486-1494. http://dx.doi.org/10.1016/j.agwat.2010.05.002

[23] Olesinski, A.A., Wolf, S., Rudich, J. and Marani, A. (1989) The Effect of Nitrogen Fertilization and Irrigation Frequency on Photosynthesis of Potatoes (Solanum tuberosum). Annals of Botany, 64, 651-657.

[24] Wright, G.C. and Rachaputi, N.C. (2008) Transpiration: Efficiency. J. Encyclopedia of Water Science, 1240-1246. 
[25] Bunce, J.A. (2003) Effects of Water Vapor Pressure Difference on Leaf Gas Exchange in Potato and Sorghum at Ambient and Elevated Carbon Dioxide under Field Conditions. Field Crops Research, 82, 37-47. http://dx.doi.org/10.1016/S0378-4290(03)00004-2

[26] Bunce, J.A. (2009) Use of the Response of Photosynthesis to Oxygen to Estimate Mesophyll Conductance to Carbon Dioxide in Water-Stressed Soybean Leaves. Plant, Cell \& Environment, 32, 875-881. http://dx.doi.org/10.1111/j.1365-3040.2009.01966.x

[27] Moorby, J. (1970) The Production, Storage, and Transpiration of Carbohydrates in Developing Potato Plants. Annals of Botany, 349, 297-308.

[28] Vos, J. and Groenwold, J. (1989b) Genetic Differences in Water-Use Efficiency, Stomatal Conductance and Carbon Isotope Fractionation in Potato. Potato Research, 32, 113-121. http://dx.doi.org/10.1007/BF02358219

[29] Malti, P.I., Aoki, M. and Ozawa, Y. (2002) Characterisation of Canopy Photosynthesis $\mathrm{CO}_{2}$ Flux and Leaf Stomatal Conductance Responses of Potato Crop to Changing Field Meterorological Conditions in Hokkaido. Journal of Agricultural Meteorology, 58, 115-122. http://dx.doi.org/10.2480/agrmet.58.115

[30] Koç, M., Barutçular, C. and Genç, I. (2003) Photosynthesis and Productivity of Old and Modern Durum Wheats in a Mediterranean Environment. Crop Science, 43, 2089-2098. http://dx.doi.org/10.2135/cropsci2003.2089

[31] Schapendonk, A., Spitters, C. and Groot, P. (1989) Effects of Water Stress on Photosynthesis and Chlorophyll Fluorescence of Five Potato Cultivars. Potato Research, 32, 17-32. http://dx.doi.org/10.1007/BF02365814

[32] Flexas, J. and Medrano, H. (2002) Drought-Inhibition of Photosynthesis in $\mathrm{C}_{3}$ Plants: Stomatal and Non-Stomatal Limitations Revisited. Annals of Botany, 89, 183-189. http://dx.doi.org/10.1093/aob/mcf027

[33] Schafleitner, R., Gutierrez, R., Espino, R., Gaudin, A., Pérez, J., Martínez, M. and Bonierbale, M. (2007) Field Screening for Variation of Drought Tolerance in Solanum tuberosum L. by Agronomical, Physiological and Genetic Analysis. Potato Research, 50, 71-85. http://dx.doi.org/10.1007/s11540-007-9030-9

[34] Zebarth, B., Tarn, T., de Jong, H. and Murphy, A. (2008) Nitrogen Use Efficiency Characteristics of Andigena and Diploid Potato Selections. American Journal of Potato Research, 85, 210-218. http://dx.doi.org/10.1007/s12230-008-9014-6

[35] Zebarth, B.J., Tai, G., Tarn, R., de Jong, H. and Milburn, P.H. (2004) Nitrogen Use Efficiency Characteristics of Commercial Potato Cultivars. Canadian Journal of Plant Science, 84, 589-598. http://dx.doi.org/10.4141/P03-050 
Scientific Research Publishing (SCIRP) is one of the largest Open Access journal publishers. It is currently publishing more than 200 open access, online, peer-reviewed journals covering a wide range of academic disciplines. SCIRP serves the worldwide academic communities and contributes to the progress and application of science with its publication.

Other selected journals from SCIRP are listed as below. Submit your manuscript to us via either submit@scirp.org or Online Submission Portal.
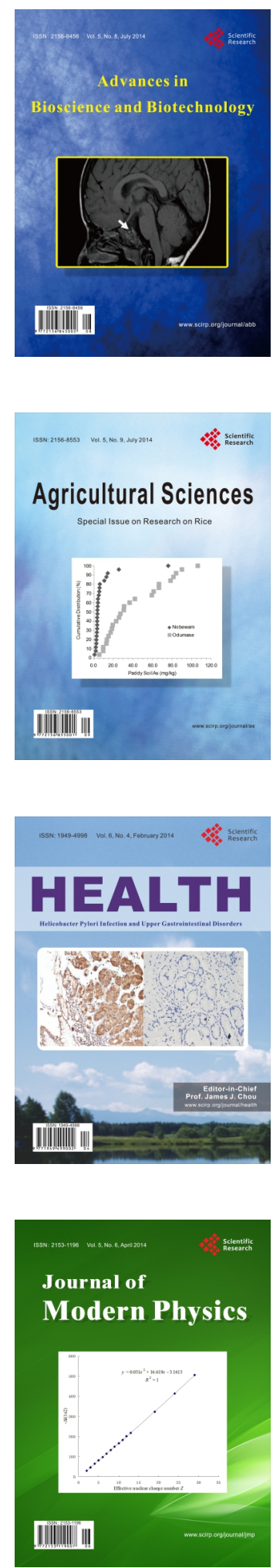
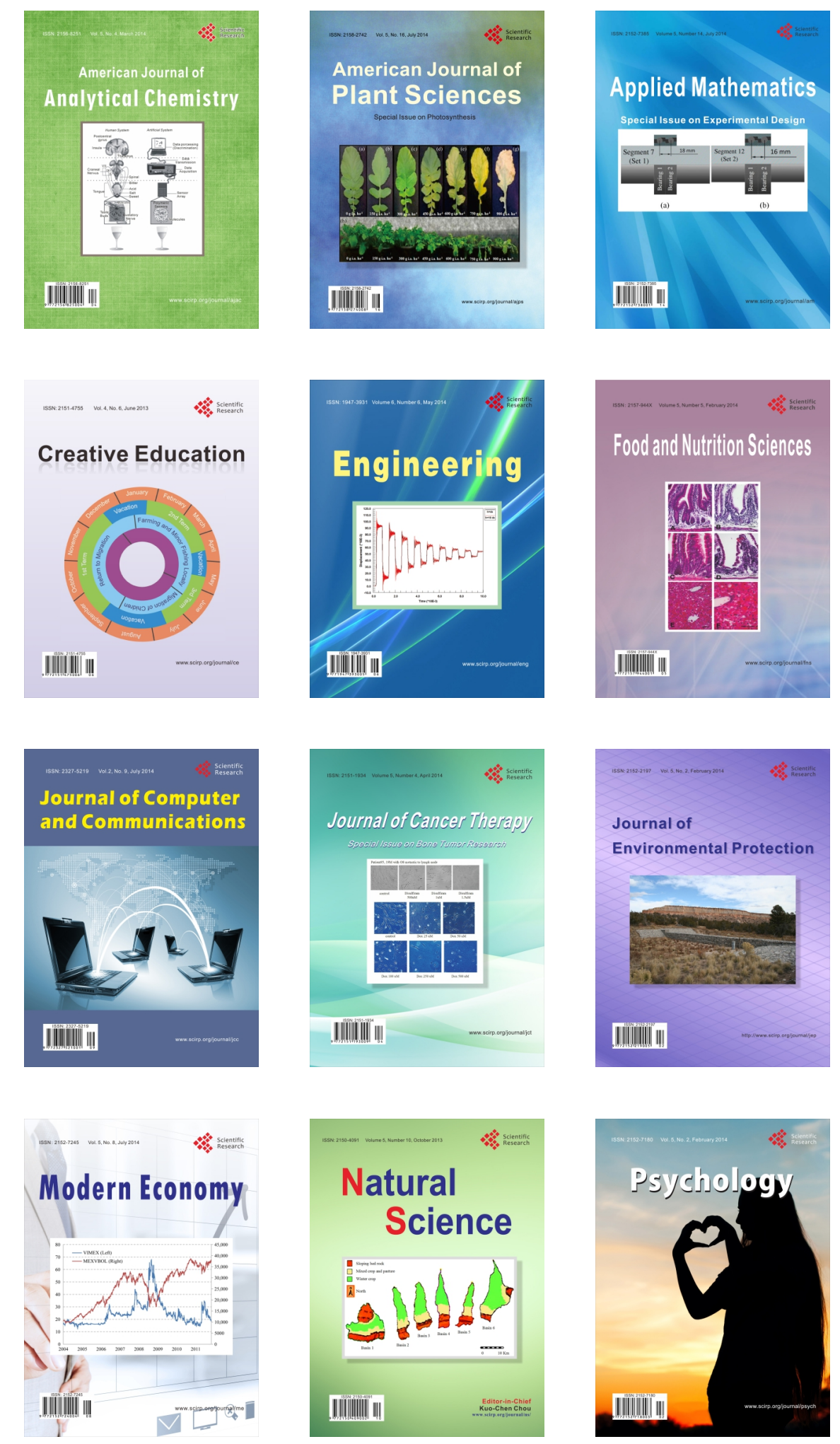